\title{
Risk factors associated with albuminuria in Rwanda: results from a STEPS survey
}

Candide Tran Ngoc ${ }^{*}$, Prebo Barango ${ }^{2}$, Roger Harrison ${ }^{3}$, Andrew Jones ${ }^{3}$, Steven Velabo Shongwe 4 , Albert Tuyishime ${ }^{5}$, François Uwinkindi ${ }^{5}$, Hongyi $\mathrm{Xu}^{6}$ and Stephanie Shoop-Worrall ${ }^{7}$

\begin{abstract}
Background: Non-communicable diseases (NCDs) are a growing burden which affects every part of the world, including developing countries. Chronic kidney disease (CKD) has varied etiology which can result from or complicate other NCDs such as diabetes and cardiovascular diseases. The growing prevalence of NCDs coupled with the increasing age in most developing countries, has seen a marked increase of CKD in these settings. CKD has been described as "the most neglected NCD" and greatly affects the quality of life of patients. It also places a huge economic burden on societies. However, few epidemiological data exist, particularly in sub-Saharan Africa. Assessment of the prevalence of albuminuria as a marker of kidney damage and CKD progression and its main risk factors was thus needed in Rwanda.

Methods: This study analyzed data collected during the first STEPwise approach to NCD risk factor Surveillance (STEPS) survey in Rwanda, conducted from 2012 to 2013, to assess the prevalence of albuminuria. A multistage cluster sampling allowed to select a representative sample of the general population. Furthermore, descriptive, as well as univariable analyses and multiple logistic regression were performed to respond to the research question.
\end{abstract}

Results: This survey brought a representative sample of 6,998 participants, among which 4,384 (62.65\%) were female. Median age was 33 years (interquartile range, IQR 26-44), and over three quarters (78.45\%) lived in rural areas. The albuminuria prevalence was 105.9 per 1,000 population. Overall, semi-urban and urban residency were associated with lower odds of CKD (odds ratio, OR 0.36, Cl 0.23-0.56, $p<0.001$ and OR $0.34, \mathrm{Cl} 0.23-0.50, p<0.001$, respectively) than rural status. Being married or living with a partner had higher odds (OR 1.44 ( $C l 1.03-2.02, p=0.031)$ and OR 1.62 (Cl 1.06-2.48, $p=0.026$ ), respectively) of CKD than being single. Odds of positive albuminuria were also greater among participants living with human immunodeficiency virus (HIV) (OR 1.64, Cl 1.09-2.47, p=0.018). Gender, age group, smoking status and vegetable consumption, body mass index (BMI) and hypertension were not associated with albuminuria.

Conclusion: The albuminuria prevalence was estimated at 105.9 per 1,000 in Rwanda. Rural residence, partnered status and HIV positivity were identified as main risk factors for albuminuria. Increased early screening of albuminuria to prevent CKD among high-risk groups, especially HIV patients, is therefore recommended.

*Correspondence: tranngocc@who.int

${ }^{1}$ World Health Organization, Country Office for Rwanda, Kigali, Rwanda Full list of author information is available at the end of the article

\section{Introduction}

Chronic kidney disease (CKD) affects approximately 10 to $15 \%$ of the global population [1], and has been described as the most neglected NCD [2]. Early-stage CKD is rarely detected $[3,4]$ and can go unnoticed until 30 to $40 \%$ of the kidney function is lost [5]. Early signs and symptoms of disease include tiredness, lack of 
appetite, itching, and changes in urination [6-8], as well as uremic symptoms and sexual dysfunction [9-12]. The condition worsens with cramps, vomiting, back pain, and bloody urine $[6,7]$ and is usually diagnosed at a late stage $[13,14]$. CKD is defined by a reduced renal glomerular filtration rate (GFR) inferior to $60 \mathrm{~mL} / \mathrm{min}$ per $1.73 \mathrm{~m}^{2}$ [12], and/or markers of kidney damage for over three months, usually marked by albuminuria [15].

Without successful treatment, CKD can progress to end-stage renal disease (ESRD), corresponding to a GFR less than $15 \mathrm{~mL} / \mathrm{min}$ per $1.73 \mathrm{~m}^{2}$ and total kidney failure [12]. As the disease progresses, major complications of CKD include hypertension, anemia, bone and electrolytes disorders and volume retention $[9,10]$. All of these greatly affect the quality of life of patients, and are linked to high mortality levels [12]. Low detection and severe complications in late-stage disease has meant that CKD figures among the three causes of death with the greatest increase from 1990 to 2015 globally [16], in contrast with other non-communicable diseases (NCDs) [16].

In low-income countries, the silent growing CKD epidemic $[17,18]$ places both a huge health and financial burden on the individuals and the society $[2,19,20]$. While management of CKD involves controlling its associated cause(s) and complications [21, 22], ESRD requires more aggressive, financially costly therapies such as renal replacement therapy (RRT) and/or kidney transplant [21, 22]. A lack of early detection, coupled with limited access to RRT for ESRD in fragile healthcare systems [23] amplifies the impact of the disease $[1,23,24]$. When detected early [4], available and affordable therapies can slow or prevent progression of CKD to ESRD [25]. Identification and screening of at-risk individuals is therefore critical [26] to reduce the risk of the disease, particularly in resource-limited settings [27, 28]. However, knowledge of risk factors for CKD, particularly on the African continent, is limited.

Although little information on CKD is available on the African continent [29-31]; recent studies estimated its prevalence in 21 countries in sub-Saharan Africa between 10.1 to $15.8 \%$ [30-34]

Some CKD risk factors are well-recognized globally, such as diabetes, hypertension and ageing [35], with diabetes being the leading cause of CKD globally [26]. However, others such as smoking and obesity may be more relevant within certain parts of the globe. Changes in lifestyles led to an increase of such risk factors in all countries of the African region, resulting in an upsurge in CKD in the region [36]. Potential additional risk factors for CKD include socio-economic status, genetic factors, infections, medicines, and environmental factors [19, 26, 37-41]. In addition to these factors, many risk factors for CKD are still unknown, especially in resource-limited countries [29]. There is thus a need to explore the extent to which this applies to other populations [32].

The World Health Organization (WHO)'s STEPS (STEPwise approach to NCD risk factor Surveillance) instrument [42] collects and analyzes information on main NCDs risk factors in a standardized way [43]. It collects information on four main behavioral NCD risk factors, namely tobacco use, alcohol consumption, diet and physical activity [44]. It also gathers evidence on four major biological risk factors for NCDs: overweight/obesity, increased blood pressure, raised blood glucose and raised cholesterol [44].

In view of the above-mentioned challenges, it was thus deemed relevant to estimate the prevalence of albuminuria as a marker of kidney damage and CKD progression [15] in Rwanda, as well as to investigate its risk factors in the country to allow an earlier detection of the at-risk people; and to inform policy-makers for improved planning. This could be comprehensively assessed using the standardized WHO STEPS approach. The main objective of this study was therefore to assess the main risk factors associated with albuminuria in Rwanda.

\section{Methods \\ Study population}

This analysis included participants recruited to the STEPS survey, a cross-sectional population-based study of NCD risk factors in Rwanda. Data collection took place between November 2012 to March 2013 [34]. The STEPS survey aimed to identify risk factors for albuminuria used a representative sample of the Rwandan population using three stage cluster sampling [44]. The overall sample size necessary for the study was deemed to be 7200 participants over ten age and sex groups, considering a $50 \%$ prevalence of risk factors, since no previous data were available, and assuming a $20 \%$ non-response rate, a 1.5 design effect to account for complex sample design, which represents the likelihood for a study participant to present the risk factor of interest and is the recommended value for most STEPS surveys [44]; 5\% margin of error and 95\% level of confidence [44]. Participants were randomly chosen using multistage cluster sampling [45] (Fig. 1) from enumeration areas (Eas) previously defined during the 2012 census [34] and corresponding to villages $[44,46]$. A maximum of one eligible individual among each of the households was randomly selected (Fig. 1). Using the Kish method [44, 47].

Inclusion criteria included: individuals within selected households aged between 15 and 64 years. Furthermore, pregnant women were excluded from height and weight measurements [44]. 


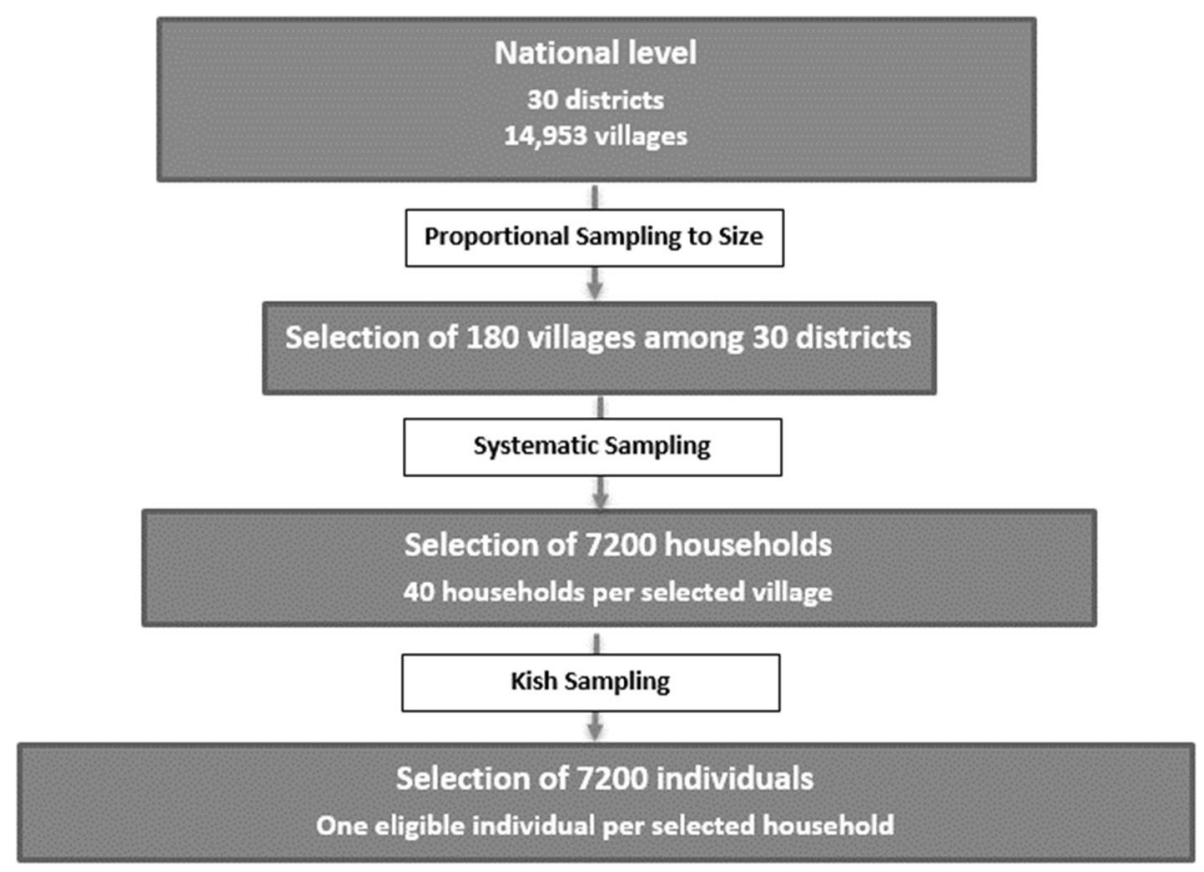

Fig. 1 Sampling flow chart

\section{Data collection}

Data collection was conducted by sixteen teams, each composed of three data collectors, one laboratory technician and one supervisor [34].

The Rwanda NCD risk factor survey used the WHO's three-step approach for surveillance of risk factors for NCDs [34], which involved:

i) Step 1: A behavioral risk factors interview through a questionnaire, which was completed for participants at their domicile for confidentiality purposes on the first day of the data collection.

ii) Step 2: Physical measurements, which took place the same day as Step 1.

iii) Step 3: Biological measurements, which took place the second day after participants had received fasting instructions on day 1.

The questionnaire included questions on behavioral risk factors for NCDs and physical and biological measurements.

For Step 1, behavioral risk factors were surveyed by data collectors using electronic portable devices such as personal digital assistants (PDAs). Demographic factors included age, sex, marriage status (single, cohabitating, married, separated, divorced, widowed residence (rural/ urban/semi-urban), level of education (no formal schooling, complete primary, complete secondary and at least undergraduate university schooling completed) and employment status (employee, self-employed, student, non-paid work, retired, unemployed). Lifestyle factors included tobacco (tobacco consumption during the past 12 months ) and alcohol use (alcohol consumption during the past 30 days), fruits and vegetables consumption (number of servings per day) and physical activity (number of days in a week with moderate physical activity ) [34].

For Step 2, blood pressure, weight and height were measured using the following devices: OMRON M4 Digital Automatic Blood Pressure Monitors; Genesis growth scales; and Figure Finder ${ }^{\circledR}$ constant tension measuring tapes, respectively [34]. Weight and height were measured to the nearest $0.1 \mathrm{~kg}$ and to the nearest whole centimeter, respectively and both were used to calculate body mass index (BMI) (underweight, normal, overweight and obese). Systolic and diastolic blood pressure was measured three times [34]; and an average of the three results was taken [34]. Hypertension was defined as a systolic blood pressure equal to or above $140 \mathrm{mmHg}$ and/or diastolic blood pressure equal to or above 90 mmHg. Participants receiving antihypertensive drugs were included into the survey.

In step 3, participants fasted from the evening of the previous day (from $10 \mathrm{PM}$ ) until measurements were made in the following morning [34]. During step 3, capillary blood samples were taken using the finger prick 
method [48], and total cholesterol $(\mathrm{mmol} / \mathrm{L}$ or $\mathrm{mg} / \mathrm{dl})$ and fasting blood glucose $(\mathrm{mmol} / \mathrm{L})$ were assessed using CardioChek PA devices [49] while human immunodeficiency virus (HIV) status was conducted using an antibody-based method. For every tenth finger-prick test, a sample of venous blood was also taken at the National Reference Laboratory for counter verification [34]. Urine samples were collected on day 1 in a non-fasting state as per WHO's guidance [44]. Raised fasting blood glucose was defined as fasting capillary blood glucose $\geq 6.1$ $\mathrm{mmol} / \mathrm{L}$ (110 mg/dl). Furthermore, participants receiving an antidiabetic treatment were included into this study. Raised total cholesterol was defined as $\geq 5.0 \mathrm{mmol} / \mathrm{L}$ or $\geq 190 \mathrm{mg} / \mathrm{dl}$.

\section{Outcome measurement}

Albuminuria was rated as positive if estimated at above $30 \mathrm{mg} / \mathrm{dl}$ using dipsticks [50]. Results were then confirmed using COBAS lab analyzers [51]; and normal laboratory values for urine albumin were $0-8 \mathrm{mg} / \mathrm{dl}$ [46]. This study therefore considered only the participants who consented to take part into step 3 and for whom albuminuria results were available. Participants with abnormal test results were then referred to the nearest health facility for further investigations and proper management of their condition if necessary [46].

\section{Statistical analysis \\ Estimating albuminuria prevalence}

Albuminuria prevalence was estimated by dividing the number of subjects with albuminuria by the total number of participants who agreed to provide urine samples. This figure was then multiplied by 10 to calculate the prevalence per 1,000 people; and results displayed by sex.

\section{Assessing risk factors for albuminuria}

Initially, associations were assessed between each risk factor and albuminuria using a Chi-squared test.

Multicollinearity between continuous variables was then tested using Spearman's correlation and variables with greater data availability were preferred from the initial demographic, biological and risk factors variables for entry to a multivariable model where significant correlations arose [52].

Furthermore, variables of clinical interest that were correlated with variables in the primary multivariable model were additionally explored as risk factors for albuminuria in secondary analyses (Supplementary materials).

All analyses were undertaken in STATA 15 (StataCorp 2017) [53].

\section{Results}

Study response rate and Power Analysis

Overall, 7,240 respondents consented to take part in the first step of this study.

Among the initial respondents, 7,224 (99.78\%) participated in Step 2 (physical measurements), while 7,161 (98.91\%) consented to take part in the final step (biological measurements). Results for albuminuria were available for 6,998 (96.66\%) participants, who comprised the final study population.

The required sample size was estimated at $n=6549$ to detect an odds ratio of at least 1.5 , or $n=6350$ to detect an odds ratio lower or equal to 0.6 , for any factor with an estimated prevalence of $10 \%$, 95\% confidence level, $90 \%$ precision and with a 1:10 ratio of people with albuminuria to those without albuminuria.

\section{Demographic, biological and lifestyle characteristics of participants}

As shown in Table 1, 4,384 (62.65\%) participants were females. Median age was 33 years (IQR 26-44). Furthermore, most of the participants (78.45\%) lived in rural areas. Most of the group $(60.40 \%)$ had no formal education; $82.09 \%$ of the participants were self-employed, and most were married (56.91\%).

Most of participants (89.12\%) reported alcohol consumption during the past 30 days and $14.63 \%$ of the survey participants had smoked any tobacco product in the past 12 months. Most subjects (78.56\%) reported daily consumption of one serving of fruit, while 48.49 and $49.63 \%$ consumed between one to two servings of vegetables per day, respectively. Moreover, 1028 (31.53\%) participants practiced a moderate physical activity six days in a week.

Three quarters (74.55\%) of subjects had a normal BMI. Most of study participants $(82.27 \%$ ) had a normal BP. Moreover, $96.89 \%$ of subjects had a normal blood cholesterol. $95.26 \%$ of study subjects had a normal fasting blood glucose. Additionally, 4.13\% were found positive for HIV.

Additionally, the proportion of selected socio-demographic, biological and behavioral characteristics of participants according to their marital status and residence is further described in the Supplementary materials. In general, older age groups, increased BMI as well as tobacco and alcohol use were more represented among married persons. This group also showed a greater proportion of participants with a higher vegetable consumption and moderate physical activity. Moreover, older age group, tobacco and alcohol use were more represented among participants living in a rural area (Supplementary materials). 
Table 1 Demographic, biological and lifestyle characteristics of participants

\begin{tabular}{|c|c|c|}
\hline & $\begin{array}{l}\text { No. of patients with } \\
\text { available data (\%) }\end{array}$ & $\begin{array}{l}\mathrm{N}(\%) \text { or Mean (SD) } \\
\text { or Median (IQR) }\end{array}$ \\
\hline \multicolumn{3}{|l|}{ Socio-demographic characteristics } \\
\hline Sex & $6998(100.00)$ & \\
\hline Male & & $2614(37.35)$ \\
\hline Female & & $4384(62.65)$ \\
\hline Age group & $6993(99.93)$ & \\
\hline $15-24$ & & $1460(20.88)$ \\
\hline $25-34$ & & $2306(32.98)$ \\
\hline $35-44$ & & $1513(21.64)$ \\
\hline $45-54$ & & $1020(14.59)$ \\
\hline $55-64$ & & $694(9.92)$ \\
\hline Residence & $6998(100.00)$ & \\
\hline Rural & & $5490(78.45)$ \\
\hline Urban & & $921(13.16)$ \\
\hline Semi-urban & & $587(8.39)$ \\
\hline Educational level & $6988(99.86)$ & \\
\hline No formal education & & $4223(60.40)$ \\
\hline Completed primary & & $2458(35.17)$ \\
\hline Completed secondary & & $200(2.86)$ \\
\hline Completed at least undergraduate university & & $107(1.53)$ \\
\hline Employment status & 6983 (99.79) & \\
\hline Employee & & $210(3.01)$ \\
\hline Self-employed & & $5732(82.09)$ \\
\hline Student & & $480(6.87)$ \\
\hline Non-paid work & & $232(3.32)$ \\
\hline Retired & & $8(0.11)$ \\
\hline Unemployed & & $321(4.60)$ \\
\hline Marital status & $6986(99.83)$ & \\
\hline Single & & $1647(23.58)$ \\
\hline Cohabitating & & $493(7.06)$ \\
\hline Married & & $3976(56.91)$ \\
\hline Separated & & $226(3.24)$ \\
\hline Divorced & & $143(2.05)$ \\
\hline Widowed & & $501(7.17)$ \\
\hline \multicolumn{3}{|l|}{ Physical and biological measurements } \\
\hline Body Mass Index (BMI) (kg/m2) & $6978(99.71)$ & $22.10(20.41-24.17)$ \\
\hline Underweight $(<18.5)$ & & $518(7.42)$ \\
\hline Normal $(<=18.5$ and $=<24.9)$ & & $5202(74.55)$ \\
\hline Overweight ( $>=25.0$ and $=<29.9$ ) & & $1017(14.57)$ \\
\hline Obese $(\mathrm{BMI}>=30.0)$ & & $241(3.45)$ \\
\hline Hypertension status & $6998(100.00)$ & \\
\hline Normal BP (systolic BP <140 mmHg and diastolic BP <90 mmHg) & & $5757(82.27)$ \\
\hline Elevated BP (systolic BP $>=140 \mathrm{mmHg}$ and/or diastolic BP $>=90 \mathrm{mmHg}$ ) & & $1241(17.73)$ \\
\hline Cholesterol status & $6973(99.64)$ & \\
\hline Normal blood cholesterol (<5 mmol/L) & & $6756(96.89)$ \\
\hline Raised blood cholesterol $(=>5 \mathrm{mmol} / \mathrm{L})$ & & $217(3.11)$ \\
\hline Diabetic status & $6629(94.73)$ & \\
\hline Absence of diabetes (capillary blood glucose $<5.6$ mmol/L) & & $6308(95.16)$ \\
\hline Impaired fasting glycaemia (capillary blood glucose $>=5.6 \mathrm{mmol} / \mathrm{L}$ and $<6.1 \mathrm{mmol} / \mathrm{L}$ ) & & $110(1.66)$ \\
\hline Raised fasting blood glucose (capillary blood glucose $>=6.1 \mathrm{mmol} / \mathrm{L}$ ) & & $211(3.18)$ \\
\hline
\end{tabular}


Table 1 (continued)

\begin{tabular}{|c|c|c|}
\hline & $\begin{array}{l}\text { No. of patients with } \\
\text { available data (\%) }\end{array}$ & $\begin{array}{l}\mathrm{N}(\%) \text { or Mean (SD) } \\
\text { or Median (IQR) }\end{array}$ \\
\hline Results of HIV test & 5519 (78.87) & \\
\hline Positive & & $228(4.13)$ \\
\hline Negative & & $5291(95.87)$ \\
\hline \multicolumn{3}{|l|}{ Risk factors for NCDs } \\
\hline Tobacco use in the past 12 months & $6991(99.90)$ & \\
\hline Yes & & $1023(14.63)$ \\
\hline No & & $5968(85.37)$ \\
\hline Alcohol use during the past 30 days & $3327(47.54)$ & \\
\hline Yes & & 2965 (89.12) \\
\hline No & & $362(10.88)$ \\
\hline Number of serving of fruit per day & 4469 (63.86) & $1(1-1)$ \\
\hline 1 & & $3511(78.56)$ \\
\hline 2 & & $841(18.82)$ \\
\hline 3 and over & & $117(2.62)$ \\
\hline Number of serving of vegetables per day & $6672(95.34)$ & $2(1-2)$ \\
\hline 1 & & 3235 (48.49) \\
\hline 2 & & $3311(49.63)$ \\
\hline 3 and over & & $126(1.89)$ \\
\hline Number of days in a week with moderate physical activity & $3260(46.58)$ & $5(3-6)$ \\
\hline 1 & & $170(5.37)$ \\
\hline 2 & & $375(11.50)$ \\
\hline 3 & & $443(13.59)$ \\
\hline 4 & & $239(7.33)$ \\
\hline 5 & & $448(13.74)$ \\
\hline 6 & & $1028(31.53)$ \\
\hline 7 & & $557(17.09)$ \\
\hline
\end{tabular}

\section{Albuminuria prevalence among study participants}

Overall, 741 out of 6,998 (10.59\%) of participants were found positive for albuminuria, which corresponds to a prevalence of 105.9 per 1,000 population.

Furthermore, albuminuria prevalence among females was almost twice than among males, with 287 (10.98\%) out of 2,614 of males and 454 (19.36\%) of 4,384 females presenting a positive albuminuria test result.

\section{Univariable associations with albuminuria}

In univariable analysis, there were significant differences in age group, residence, hypertensive and HIV status and levels of physical activity between people with and without albuminuria (Figs. 2, 3 and 4 and fifth column of Table 2).

Furthermore, additional analyses explored the association between selected socio-demographic, biological and behavioral variables and are described in the Supplementary materials.

\section{Multivariable assessment of risk factors associated with albuminuria}

All socio-demographic variables were included into the (adjusted) primary model. Among biological and behavioural variables, vegetable consumption, tobacco use and hypertension were retained in the multivariable model as they showed a greater data availability while variables found collinear with these factors (fruit consumption, physical activity, alcohol consumption, blood glucose, cholesterol) were excluded.

Following multivariable adjustment, semi-urban and urban residency were associated with lower odds of albuminuria (OR 0.36, CI 0.23-0.56, $p<0.001$ and OR 0.34, CI $0.23-0.50, p<0.001$, respectively) than rural status. Additionally, being married or living with a partner had higher odds of albuminuria than being single, with ORs of 1.44 (CI 1.03-2.02, $p=0.031)$ and 1.62 (CI 1.06-2.48, $p=0.026$ ), respectively. Sex of the participant, age group, educational and employment status were not associated with the odds of prevalent albuminuria and tobacco use and 


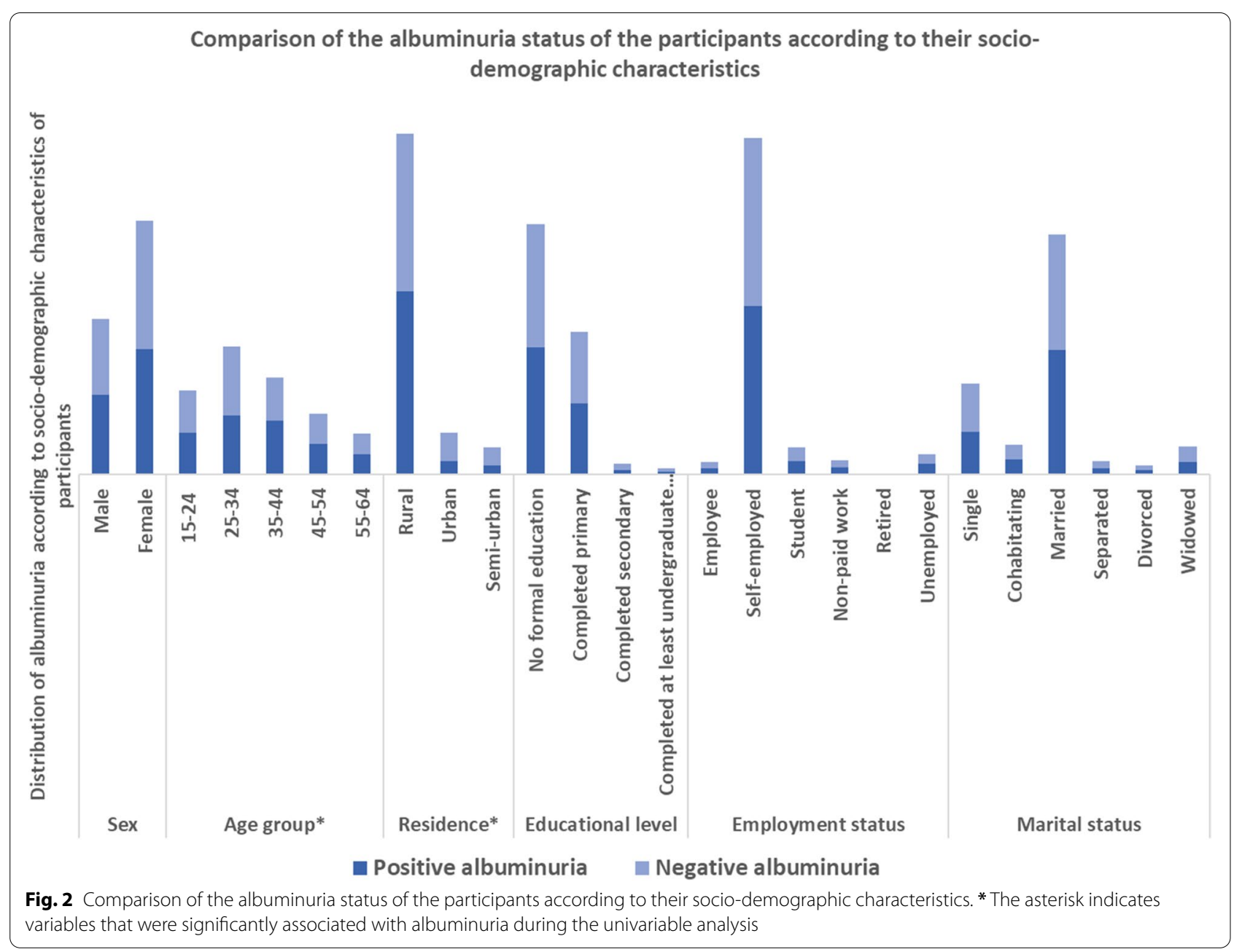

vegetable consumption were also not associated with the condition.

Among biological variables, odds of albuminuria were greater among participants living with HIV (OR 1.64, CI 1.09- 2.47, $p=0.018$ ), while BMI and hypertension status showed no association with the condition (Table 2).

In secondary analyses, diabetic status was not associated with albuminuria (Supplementary materials, model 2).

Furthermore, we grouped the participants of this study according to their blood pressure [54] and assessed their respective odds for developing albuminuria. Results of this secondary analysis showed no significant association between elevated blood pressure and albuminuria and are shown in Supplementary materials (model 3).

\section{Discussion}

We estimated an albuminuria prevalence of $10.59 \%$ (95\% CI 9.98-11.33), or 105.9 in 1,000 people in Rwanda. Rural or semi-urban residency category, being married or living with a partner and HIV positivity were significantly associated with higher odds of albuminuria. However, sociodemographic variables such as age and sex as well as risk factors such as tobacco use and vegetable consumption; and biological variables like increased BMI and elevated blood pressure were not associated with albuminuria.

This study reports an albuminuria prevalence of 10.59\% (95\% CI 9.98-11.33). Wyatt et al. (2011) estimated the prevalence of proteinuria at $8.7 \%$ among Rwandan HIV-negative women [33]. This latter is, to the best of our knowledge, one of the few published studies reporting a proteinuria prevalence in Rwanda. The higher prevalence reported in the current study may be attributed to the population-based approach, which included a more diverse study population than the female-only population in Wyatt et al. [33]. In broader populations, similar to the current study, a multisite survey conducted in four countries in Southern, Western and Eastern Africa, found an overall albuminuria prevalence of $9.2 \%$ (95\% CI 8.4-10.0). However, albuminuria 


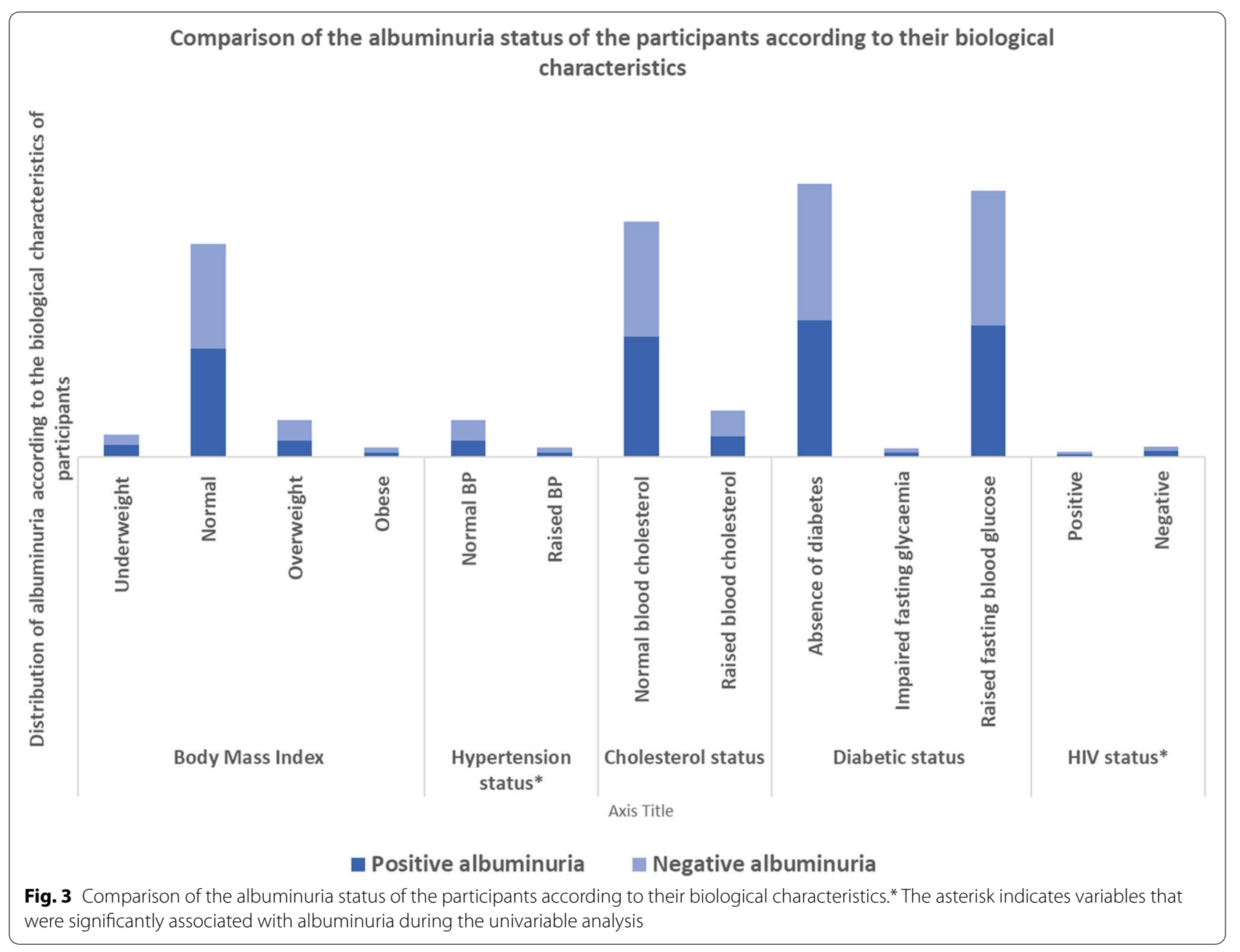

prevalence was reported to vary regionally according to differences socioeconomic status in sub-Saharan Africa [55], potentially explaining a higher overall CKD prevalence of $13.9 \%$ (95\% CI 12.2-15.7) in a meta-analysis on CKD prevalence which gathered 90 studies in sub-Saharan Africa in 2014 [30]. The high albuminuria prevalence reported in our study and corroborated in other studies from across Africa suggest the need for increased CKD prevention measures in Rwanda, particularly since patients with CKD in resource-constraint countries do not currently have access to hemodialysis or renal replacement therapies [56].

Residency status was identified as risk factor for albuminuria in the current study. Compared with residing in a rural location, living in an urban or semi-urban area indeed indicated a protective effect against albuminuria. This results could be unexpected, as urban lifestyles have been associated with unhealthy lifestyle behaviors such as sedentarity or obesity [57-59]. They might be partly explained by disparities in accessing health care.
Studies conducted in Thailand, China and Cameroon indeed reported limited access to sanitation and health care [60], lower socioeconomic status and health literacy $[37,61]$ and greater use of herbal medicine and street medications [62] in rural areas compared with urban zones. Therefore, in the area of the Sustainable Development Goals (SDGs) [2] and the motto of leaving no one behind, the Social Determinants of Health (SDH) [63]; should be addressed in a comprehensive manner across all sectors, including inequities in terms of gender and access to health care. Indeed, although Rwanda figures among the few countries in sub-Saharan Africa with government funding for some eligible patients with end-stage renal disease [64]; financial barriers, mainly linked to the high cost of treatment [56], still limit access to renal replacement therapy. A stronger implementation of the WHO's Health in All Policy framework [65], such as policies aiming at reducing poverty and environmental pollution; and raising awareness on CKD among school-aged 




population, could thus be beneficial to tackle this disease.

Moreover, being married or living in a union was associated with greater odd of developing albuminuria. This corroborates findings from Bangladesh, where married participants showed a greater tendency to develop CKD than unmarried study subjects [66]. This might be due to an increase in risk factors for NCDs among partnered persons, possibly because partnered persons may be more likely to be older than non-partnered participants, as described in our study, which indicated a higher proportion of older age groups and tobacco and alcohol consumption among married persons; or more likelihood of sedentary lifestyle. For example, married men in Germany and the United States have been reported to have an increased BMI and less physical activity [67, 68]. Similarly, increased BMI was more represented among married participants in our study. The proportion of participants who had a higher moderate physical activity was however greater among married persons, but the lower response rate (less than 50\%) associated with this variable might have influenced the results. Additionally, a study conducted in Kenya found higher odds (1.58) of NCD risk factors among married women, but not men [69]. On the other hand, divorced women tended to report worse health than married women in Australia, while no association was found between marital status and health for men [70]. The later could be partly explained by greater shared economic resources among married people compared to other marital statuses and access to a spouse's health insurance, especially for women [71, 72]. However, a South African study found no association between marital status and NCDs [73].; while married and separated/ divorced/ widower truck drivers in Ethiopia were respectively over three times and two times more at risk of developing NCDs [74]. Moreover, duration of partnership, as well as the bias of self-reporting on partnership considering social acceptability and expectation are other factors that may be further explored in view of the association reported. 
Table 2 Results of the univariable and multivariable analyses

\begin{tabular}{|c|c|c|c|c|c|}
\hline \multirow[t]{2}{*}{ Variable } & \multirow[t]{2}{*}{ Variable category } & \multicolumn{2}{|c|}{ Urine albumin } & \multirow[t]{2}{*}{ Univariable $p$-value } & \multirow{2}{*}{$\begin{array}{l}\text { Multivariable OR 95\% } \\
\text { confidence interval (CI) }\end{array}$} \\
\hline & & $\begin{array}{l}\text { Positive } \\
\mathrm{N}(\%)\end{array}$ & $\begin{array}{l}\text { Negative } \\
\mathrm{N}(\%)\end{array}$ & & \\
\hline \multicolumn{6}{|l|}{ Socio-demographic characteristics } \\
\hline \multirow[t]{2}{*}{ Sex } & Male & $287(38.73)$ & $2327(37.19)$ & 0.412 & Reference \\
\hline & Female & $454(61.27)$ & $3930(62.81)$ & & $0.99(0.81-1.21)$ \\
\hline \multirow[t]{5}{*}{ Age group } & $15-24$ & $149(20.11)$ & $1311(20.97)$ & 0.017 & Reference \\
\hline & $25-34$ & $214(28.88)$ & $2092(33.46)$ & & $0.87(0.62-1.20)$ \\
\hline & $35-44$ & $193(26.05)$ & $1320(21.11)$ & & $1.17(0.83-1.66)$ \\
\hline & $45-54$ & $111(14.98)$ & $909(14.54)$ & & $0.92(0.62-1.38)$ \\
\hline & $55-64$ & $74(9.99)$ & $620(9.92)$ & & $0.98(0.61-1.58)$ \\
\hline \multirow[t]{3}{*}{ Residence } & Rural & $662(89.34)$ & $4828(77.16)$ & $<0.001$ & Reference \\
\hline & Urban & $48(6.48)$ & $873(13.95)$ & & $0.34(0.23-0.50)$ \\
\hline & Semi-urban & $31(4.18)$ & $556(8.89)$ & & $0.36(0.23-0.56)$ \\
\hline \multirow[t]{4}{*}{ Educational level } & No formal education & $459(61.94)$ & $3764(60.25)$ & 0.484 & Reference \\
\hline & Completed primary & $256(34.55)$ & $2202(35.25)$ & & $1.1(0.90-1.34)$ \\
\hline & Completed secondary & $15(2.02)$ & $185(2.96)$ & & $0.96(0.52-1.79)$ \\
\hline & $\begin{array}{l}\text { Completed at least under- } \\
\text { graduate university }\end{array}$ & $11(1.48)$ & $96(1.54)$ & & $1.15(0.48-2.77)$ \\
\hline \multirow[t]{6}{*}{ Employment status } & Employee & $21(2.84)$ & $189(3.03)$ & 0.918 & Reference \\
\hline & Self-employed & $607(82.14)$ & $5125(82.08)$ & & $0.95(0.52-1.72)$ \\
\hline & Student & $46(6.22)$ & $434(6.95)$ & & $1.35(0.62-2.91)$ \\
\hline & Non-paid work & $25(3.38)$ & $207(3.32)$ & & $1.05(0.47-2.35)$ \\
\hline & Retired & $1(0.14)$ & $7(0.11)$ & & $3.8(0.36-40.48)$ \\
\hline & Unemployed & $39(5.28)$ & $282(4.52)$ & & $1.82(0.92-3.59)$ \\
\hline \multirow[t]{6}{*}{ Marital status } & Single & $152(20.57)$ & $1495(23.93)$ & 0.202 & Reference \\
\hline & Cohabitating & $53(7.17)$ & $440(7.04)$ & & $1.62(1.06-2.47)$ \\
\hline & Married & $450(60.89)$ & $3526(56.44)$ & & $1.44(1.03-2.02)$ \\
\hline & Separated & $22(2.98)$ & $204(3.27)$ & & $1.27(0.69-2.33)$ \\
\hline & Divorced & $17(2.30)$ & $126(2.02)$ & & $1.63(0.83-3.19)$ \\
\hline & Widowed & $45(6.09)$ & $456(7.30)$ & & $1.26(0.75-2.09)$ \\
\hline \multicolumn{6}{|l|}{ Biological risk factors for CKD } \\
\hline \multirow[t]{4}{*}{ Body mass index } & Normal & $570(76.92)$ & $4632(74.27)$ & 0.053 & Reference \\
\hline & Underweight & $63(8.50)$ & $455(7.30)$ & & $1.03(0.71-1.49)$ \\
\hline & Overweight & $85(11.47)$ & $932(14.94)$ & & $0.83(0.63-1.08)$ \\
\hline & Obese & $23(3.10)$ & $218(3.50)$ & & $1.15(0.68-1.93)$ \\
\hline \multirow[t]{2}{*}{ Hypertension status } & Normal BP & $633(85.43)$ & $5124(81.89)$ & 0.017 & Reference \\
\hline & Elevated BP & $108(14.57)$ & $1133(18.11)$ & & $0.79(0.61-1.03)$ \\
\hline \multirow[t]{2}{*}{ Cholesterol status } & Normal blood cholesterol & $714(96.75)$ & $6042(96.90)$ & 0.817 & Not included into the primary \\
\hline & Raised blood cholesterol & $24(3.25)$ & $193(3.10)$ & & model \\
\hline \multirow[t]{3}{*}{ Diabetic status } & Absence of diabetes & $605(93.51)$ & $5703(95.34)$ & 0.104 & Not included into the primary \\
\hline & Impaired fasting glycaemia & $13(2.01)$ & $97(1.62)$ & & model \\
\hline & Raised fasting blood glucose & $29(4.48)$ & $182(3.04)$ & & \\
\hline \multirow[t]{2}{*}{ HIV status* } & Positive & $33(5.78)$ & $195(3.94)$ & 0.037 & Reference \\
\hline & Negative & $538(94.22)$ & $4753(96.06)$ & & $1.64(1.09-2.47)$ \\
\hline \multicolumn{6}{|l|}{ Behavioral risk factors for CKD } \\
\hline \multirow{2}{*}{$\begin{array}{l}\text { Tobacco use during the past } 12 \\
\text { months }\end{array}$} & No & $117(15.79)$ & $906(14.50)$ & 0.346 & Reference \\
\hline & Yes & $624(84.21)$ & $5344(85.50)$ & & $1.02(0.77-1.35)$ \\
\hline \multirow{2}{*}{$\begin{array}{l}\text { Alcohol consumption during } \\
\text { the past } 30 \text { days }\end{array}$} & Yes & $372(90.51)$ & $2593(88.92)$ & 0.333 & \multirow{2}{*}{$\begin{array}{l}\text { Not included into the primary } \\
\text { model }\end{array}$} \\
\hline & No & 39 (9.49) & $323(11.08)$ & & \\
\hline
\end{tabular}


Table 2 (continued)

\begin{tabular}{|c|c|c|c|c|c|}
\hline \multirow[t]{2}{*}{ Variable } & \multirow[t]{2}{*}{ Variable category } & \multicolumn{2}{|c|}{ Urine albumin } & \multirow[t]{2}{*}{ Univariable $p$-value } & \multirow{2}{*}{$\begin{array}{l}\text { Multivariable OR 95\% } \\
\text { confidence interval (CI) }\end{array}$} \\
\hline & & $\begin{array}{l}\text { Positive } \\
\text { N (\%) }\end{array}$ & $\begin{array}{l}\text { Negative } \\
\mathrm{N}(\%)\end{array}$ & & \\
\hline \multirow{3}{*}{$\begin{array}{l}\text { Number of serving of fruit per } \\
\text { day }\end{array}$} & 1 & $361(78.31)$ & $3150(78.59)$ & \multirow[t]{3}{*}{0.988} & \multirow{3}{*}{$\begin{array}{l}\text { Not included into the primary } \\
\text { model }\end{array}$} \\
\hline & 2 & $88(19.09)$ & 753 (18.79) & & \\
\hline & 3 and over & $12(2.60)$ & $105(2.62)$ & & \\
\hline \multirow{3}{*}{$\begin{array}{l}\text { Number of serving of vegeta- } \\
\text { bles per day }\end{array}$} & 1 & $357(50.14)$ & $2878(48.29)$ & \multirow[t]{3}{*}{0.545} & Reference \\
\hline & 2 & $340(47.75)$ & $2971(49.85)$ & & $0.88(0.73-1.06)$ \\
\hline & 3 and over & $15(2.11)$ & $111(1.86)$ & & $0.612(0.64-2.14)$ \\
\hline \multirow{7}{*}{$\begin{array}{l}\text { Number of days in a week with } \\
\text { moderate physical activity }\end{array}$} & 1 & $21(5.57)$ & $149(5.17)$ & \multirow[t]{7}{*}{$<0.001$} & \multirow{7}{*}{$\begin{array}{l}\text { Not included into the primary } \\
\text { model }\end{array}$} \\
\hline & 2 & $36(9.55)$ & $339(11.76)$ & & \\
\hline & 3 & $41(10.88)$ & $402(13.94)$ & & \\
\hline & 4 & $19(5.04)$ & $220(7.63)$ & & \\
\hline & 5 & $33(8.75)$ & 415 (14.39) & & \\
\hline & 6 & $130(34.48)$ & $898(31.15)$ & & \\
\hline & 7 & $97(25.73)$ & $460(15.96)$ & & \\
\hline
\end{tabular}

Despite the associations between socioeconomic status and partner status and albuminuria reported in the current study, further sociodemographic variables such as age group and gender were not associated with this risk factor for CKD. CKD prevalence in the elderly is usually higher than in the general population, mainly due to changes in the structure of the kidneys [75]. Absence of association between age and albuminuria may be explained by the relatively young age of the participants of this study, as well as survival bias. Participants with albuminuria may indeed have already died at the time of this study compared with subjects with healthy kidneys resulting in a higher representation of non-CKD persons among the older participants [76]. This is sadly the case in settings with limited access to treatment, especially among the poorest populations [37].

In terms of gender, Zhang et al. (2008) similarly reported little difference in CKD prevalence between men and women China [77]. However, differences in CKD risk between genders have been reported across multiple populations, including China [78], US [79], Tanzania [80] and France [81], with females more commonly reported at increased odds . These associations are however complex, and need to account for other factors, such as gender variations in body size [82]-which influences the measurement of the renal function; and socioeconomic disparities, which also influence the sex distribution of the disease [83]. After having accounted for body size through BMI and for socioeconomic factors such as education and employment; this study found that gender was not independently associated with CKD.
Similarly, lifestyle factors such as smoking showed no statistically significant association with albuminuria. Although smoking is known as a risk factor for cardiovascular disease, its role as independent risk factor for CKD is less apparent [84]. Heavy smoking status is indeed directly linked with CKD $[85,86]$, as demonstrated in the United States [87] and in Syria [86]. The absence of information on the daily use of tobacco products in this research could partly explain the absence of association between smoking and albuminuria in the current study. Furthermore, results from the 2013 STEPS survey indicate that smoking prevalence increases with age in Rwanda [34]. The relatively low [15-64] age range of the subjects may have masked a possible association between smoking and albuminuria in this study. Moreover, as smoking is associated with both greater odds of dying and development and progression of CKD [86, $88]$, survival bias $[89,90]$ could thus explain the absence of association between smoking and CKD. Additionally, we found no relationship between vegetable consumption and albuminuria. Although increased vegetable consumption has been reported to lower the mortality from all causes and NCDs, particularly cardio-vascular diseases [91-93]; less evidence exists on the direct effect of vegetable consumption on CKD [94]. A Korean cohort study indicated a protective effect of high vegetable consumption for the renal function compared to low vegetable regimen [95]. However, there was limited scope to understand the association between high and low vegetable consumption with CKD in the current study, with the majority (99\%) of participants in the current study consuming between one and two portions of vegetables per 
day and no available questionnaire option to indicate an absence of vegetable consumption.

Although lifestyle factors were not associated with albuminuria in the current study, HIV positive status was significantly associated with greater odds of prevalent albuminuria. This corroborates results from a systematic review conducted on the African continent, which indicated that HIV infection was a key risk factor for CKD, especially in contexts with higher HIV prevalence [31]. CKD has been reported in between 3.5 to $48.5 \%$ of HIV cases, particularly among young adults of African descent $[96,97]$. The association between HIV and CKD may be driven by two distinct pathways. Firstly, HIV positivity may be associated with decreased renal function [98] and CKD, mainly due to the local infection of renal cells by the virus $[99,100]$. Secondly, long-term nephrotoxicity of antiretroviral drugs may drive this association [101], with a prospective international cohort study reporting that antiretrovirals, especially associations of tenofovir and atazanavir, were associated with CKD [102]. As HIV was found to be a main contributor to the risk of CKD, the renal function should thus be monitored among HIV patients [103]. Additionally, national treatments HIV guidelines may be amended according to the current evidence, especially regarding the monitoring of renal function and the use of certain combinations of antiretrovirals.

HIV was the only biological factor measured in the current study that associated with albuminuria. There was no association between elevated blood pressure and CKD. Hypertension figures among the well-known risk factors for CKD in the United States [104]. The absence of association between hypertension and albuminuria in this study could be due to antihypertensive drugs taken by the participants. However, this information was lacking for over $99 \%$ of the study participants. Furthermore, our study found no association between increased BMI and CKD. This is similar with findings from a study using data of the descendants of the Framingham Heart Study in the United States; which indicated no association between overweight or obesity and CKD incidence [105].

This population-based survey followed a robust crosssectional survey design (STEPS) and allowed the estimation of the national estimate of the prevalence of albuminuria as a key risk factor for CKD in Rwanda, which had been sparsely documented. The STEPS methodology, developed according to current evidence and best practices, permitted to collect and analyze the data in a standardized manner, allowing comparison over time and between countries. In addition, the large sample size and detailed data collection allowed for the exploration of risk factors for albuminuria [106]. Furthermore, our study brought additional evidence on albuminuria prevalence in Rwanda, and factors that may influence its prevalence. Indeed, no nationally representative studies on albuminuria prevalence had been published prior to this work, which generated an accurate estimate of the albuminuria prevalence in Rwanda. Our findings, such as association between residence status and albuminuria, may also be generalizable to developing countries, where non-traditional risk factors for CKD such as the use of herbal/traditional medicine, are more common [60,62].

The initial STEPS survey was not specifically designed to assess for the prevalence of albuminuria as a key risk factor for CKD but rather to estimate the prevalence of main risk factors related to NCDs in general using a cross-sectional design. The prevalence of albuminuria was therefore assessed using a single measurement, which is a more practical way of screening for CKD than GFR estimation techniques, although it may lead to an overestimation of its prevalence, given the daily variability of albuminuria [107-109] and the possible occurrence of other situations and conditions such as menstrual contamination, urinary infection, temporary illnesses, and strenuous exercise, among others; that could result in transient albuminuria [12]. The presence and severity of CKD can indeed be measured using several methods including: markers of exogenous filtration or blood markers and various GFR-estimating equations indeed exist to assess the GFR [110, 111]; while urinary albumin to creatinine ratio or urine protein dipstick tests measure albuminuria $[111,112]$. However, although repeated complex measurements may improve the accuracy of results; their use can challenge the daily clinical practice [111], especially in developing countries, which often lack the resources, skilled laboratory workforce and quality laboratory equipment to perform such tests [113]. Therefore, a single measurement of albuminuria could be cost saving given its discriminative value as a marker of kidney damage [114]. Affordable point of care urine dipstick tests are indeed useful for albuminuria screening and have indicated a high negative predictive value $[115,116]$. However, high false-positive rates associated with such tests require laboratory confirmation [116], which was conducted during this study; and study participants with abnormal test results were then referred to the nearest health facility for further investigations and assessment of their renal condition [46]. This follows the KDIGO protocol for individuals demonstrating a positive reagent strip test, which recommends laboratory confirmation of persistent albuminuria on at least two additional occasions, which could also help to exclude the other possible causes of transient albuminuria [12]. 
Some factors specially related to CKD, such as the use of drugs, exposure to heavy metals and genetics [117] may have thus been omitted. Moreover, associations could not be interpreted as causal due to the cross-sectional nature of the study [106]. Additionally, the questionnaire included self-reported data. Recall biases may thus have occurred, masking some association between the independent variables and albuminuria [118]. Furthermore, this population-based survey included more women $(62.82 \%)$ than men for all age groups, while the 2012 census indicated that women aged 15-64 years accounted for $51.84 \%$ of the population in Rwanda [119]. A possible explanation may be that women were more likely to be present at home during the data collection which took place during the farming period [34]. However, we didn't find any independent gender differences during this study. Additionally, albuminuria was used as the sole marker of the renal function as per WHO's STEPS guidelines [44]. However, the KDIGO guidelines recommends urine albumin-to-creatinine ratio (ACR); and GFR equation to evaluate the glomerular filtration rate [12]. Our study used urine dipsticks as first assessment of the renal function because they were relatively inexpensive and more practical in community screening, with a high negative predictive value and minimal risk of a missed diagnosis of CKD [12]. We also conducted laboratory confirmation for positive cases as per international recommendations $[12,116]$. However, results from the comparison of dipstick and laboratory tests were not available for this secondary analysis.

\section{Conclusion}

Our study reports a prevalence of albuminuria of $10.59 \%$ in Rwanda. Participants residing in rural areas, partnered persons and HIV positive individuals had greater associations with this condition, which is a marker of kidney damage and CKD progression. Improved screening among most-at-risk individuals, including early screening for CKD among the HIV patients is thus needed. However, as CKD is influenced by other social determinants for health, the role of additional causes such as malnutrition and environmental factors, e.g. exposure to nephrotoxic drugs or agents, should be further explored to ensure that CKD doesn't remain a "neglected chronic disease".

\footnotetext{
Abbreviations

NCDs: Non-communicable diseases; CKD: Chronic kidney disease; STEPS: STEPwise approach to NCD risk factor Surveillance; IQR: Interquartile range; OR: Odds ratio; HIV: Human immunodeficiency virus; BMl: Body mass index; GFR: Glomerular filtration rate; ESRD: End-stage renal disease; WHO: World Health Organization; EAs: Enumeration areas; RNEC: Rwanda National Ethics Committee; PDAs: Personal digital assistants; ACR: Albumin-to-creatinine ratio.
}

\section{Supplementary Information}

The online version contains supplementary material available at https://doi. org/10.1186/s12882-021-02574-w.

Additional file 1.

\section{Acknowledgements}

We would like to recognize the participants who consented to part into this study, the nurses and laboratory technicians who collected the data, and the World Health Organization and other stakeholders who supported this study. A special thanks to the Rwanda Biomedical Center which granted access to the research dataset, and the STEPS study coordinator, Mr. Alypio Nyandwi, for his availability and help in getting clarifications on some aspects of the project.

This work formed part of a dissertation for a Master in Public Health, through the Faculty of Biology, Medicine and Health at the University of Manchester.

\section{Authors' contributions}

CTN contributed to the design, acquisition of data, analysis, interpretation of results and drafting of the work; SSW contributed to the design, interpretation of results and elaboration of the paper; AJ, HX, PB, SVS, RH, AT, FU participated in the interpretation of data and revision of the manuscript. The author(s) read and approved the final manuscript.

\section{Funding}

The initial STEPs survey was funded by the Ministry of Health of Rwanda and World Health Organization, the Center for Diseases Prevention and Control (CDC), the Global Fund and the Belgian Development Agency (BTC) in 2012 13. Financial support does not apply to this secondary analysis (design of the study, analysis, interpretation of data, and writing of the manuscript) of STEPS data.

\section{Availability of data and materials}

The data that support the findings of this study are available from the Rwanda Biomedical Center but restrictions apply to the availability of these data, which were used under written ethical clearance for the current study, and so are not publicly available. Data are however available from the authors (Dr. Candide Tran $\mathrm{Ngoc}$ ) upon reasonable request and with permission of the Rwanda Biomedical Center.

\section{Declarations}

Ethics approval and consent to participate

The STEPS survey was approved by the Rwanda National Ethics Committee (RNEC) [34]. Study participants were provided with a consent form in English and Kinyarwanda; and provided both written informed and oral consent [34]. Written informed assent was obtained from a parent or legal guardian for participants under 18 years old or for participants who were illiterate. Furthermore, participants provided separate consent for participating in step 3, which involved biochemical measurements [46].

All procedures were performed in accordance with relevant guidelines.

Consent for publication

Not applicable.

Competing interests

The authors declare that they have no competing interests.

\section{Author details}

${ }^{1}$ World Health Organization, Country Office for Rwanda, Kigali, Rwanda. ${ }^{2}$ World Health Organization, Inter Country Support Team, Eastern and Southern Africa, Harare, Zimbabwe. ${ }^{3}$ Division of Population Health, Health Services Research \& Primary Care, The University of Manchester, Manchester, UK. ${ }^{4}$ World Health Organization, Regional Office for Africa, Brazzaville, Republic of Congo. ${ }^{5}$ Rwanda Biomedical Center, Kigali, Rwanda. ${ }^{6}$ World Health Organization, Headquarters, Geneva, Switzerland. ${ }^{7}$ Division of Musculoskeletal and Dermatological Sciences, The University of Manchester, Manchester, UK. 
Received: 26 May 2021 Accepted: 25 October 2021

Published online: 01 November 2021

\section{References}

1. International Society of Nephrology. International Society of Nephrology [Internet]. 2018 [cited 2018 Dec 4]. Available from: https://www. theisn.org/focus/ckd\#closing-the-gaps

2. Luyckx VA, Tonelli M, Stanifer JW. The global burden of kidney disease and the sustainable development goals. Bull World Health Organ. 2018;96(6):414-422D [cited 2018 Nov 26] Available from: http://www. who.int/entity/bulletin/volumes/96/6/17-206441.pdf.

3. Wouters OJ, O’Donoghue DJ, Ritchie J, Kanavos PG, Narva AS. Early chronic kidney disease: diagnosis, management and models of care. Nat Rev Nephrol. 2015;11(8):491-502 Available from: https:/www.ncbi. nlm.nih.gov/pubmed/26055354.

4. Król E, Rutkowski B, Czarniak P, Kraszewska E, Lizakowski S, Szubert R, et al. Early detection of chronic kidney disease: results of the PolNef study. Am J Nephrol. 2009;29(3):264-73 Available from: https://www. ncbi.nlm.nih.gov/pubmed/18812692.

5. Cleveland Clinic. Chronic Kidney Disease Symptoms \& Treatment Cleveland Clinic [Internet]. 2019 [cited 2019 Feb 28]. Available from: https://my.clevelandclinic.org/health/diseases/15096-kidney-diseasechronic-kidney-disease

6. American Kidney Fund. Chronic Kidney Disease (CKD) Symptoms, Treatment, Causes \& Prevention - American Kidney Fund (AKF) [Internet]. 2019 [cited 2019 Feb 7]. Available from: http://www.kidneyfund.org/ kidney-disease/chronic-kidney-disease-ckd/\#symptoms

7. NHS. Chronic kidney disease - Symptoms - NHS [Internet]. 2019 [cited 2019 Mar 6]. Available from: https://www.nhs.uk/conditions/kidneydisease/symptoms/

8. Brown SA, Tyrer FC, Clarke AL, Lloyd-Davies LH, Stein AG, Tarrant C, et al. Symptom burden in patients with chronic kidney disease not requiring renal replacement therapy. Clin Kidney J. 2017:10(6):788-96 Available from: https://www.ncbi.nlm.nih.gov/pubmed/29225808.

9. Bello AK, Alrukhaimi M, Ashuntantang GE, Basnet S, Rotter RC, Douthat WG, et al. Complications of chronic kidney disease: current state, knowledge gaps, and strategy for action. Kidney Int Suppl. 2017;7(2):122-9 Available from: http://www.sciencedirect.com/science/article/pii/S2157 171617300333

10. Yang M, Fox CH, Vassalotti J, Choi M. Complications of Progression of CKD. Adv Chronic Kidney Dis. 2011;18(6):400-5 Available from: http:// www.sciencedirect.com/science/article/pii/S1548559511001418.

11. van der Walt I, Swanepoel CR, Mahala B, Meyers AM. Important complications of chronic kidney disease. South African Medical Journal. 2015;105:321.

12. Kidney Disease: Improving Global Outcomes (KDIGO) CKD Work Group. KDIGO clinical practice guideline for the evaluation and management of chronic kidney disease. Kidney Inter Suppl. 2013;3(1):1-150 Available from: https://kdigo.org/wp-content/uploads/2017/02/KDIGO_2012_ CKD_GL.pdf.

13. NHS. Chronic kidney disease - NHS [Internet]. [cited 2019 Feb 27]. Available from: https://www.nhs.uk/conditions/kidney-disease/

14. Webster AC, Nagler EV, Morton RL, Masson P. Chronic kidney disease Lancet. 2017;389(10075):1238-52 [cited 2018 Dec 4] Available from: http://www.ncbi.nlm.nih.gov/pubmed/27887750.

15. Kidney Disease: Improving Global Outcomes (KDIGO) CKD Work Group. Summary of recommendation statements. Kidney Int Suppl. 2013;3(1):5-14 Available from: https://pubmed.ncbi.nlm.nih.gov/25598 998.

16. Neuen BL, Chadban SJ, Demaio AR, Johnson DW, Perkovic V. Chronic kidney disease and the global NCDs agenda. BMJ Glob Heal. 2017 2(2):e000380-e000380. Available from: https://www.ncbi.nlm.nih.gov/ pubmed/29225940

17. Nugent RA, Fathima SF, Feigl AB, Chyung D. The burden of chronic kidney disease on developing nations: A 21st century challenge in global health. Nephron Clin Pract. 2011;118(3):c269-77. https://doi.org/ 10.1159/000321382

18. Bello A, Levin A, Tonelli M, Okpechi I, Feehally J, Harris D, et al. Global Kidney Health Atlas: A report by the International Society of
Nephrology on the current state of organization and structures for kidney care across the globe. [Internet]. Brussels; 2017 [cited 2019 Jan 25]. Available from: https://www.theisn.org/images/ISN_advocacy/GKHAt las_Linked_Compressed1.pdf

19. Jha V, Garcia-Garcia G, Iseki K, Li Z, Naicker S, Plattner B, et al. Chronic kidney disease: global dimension and perspectives. Lancet. 2013;382(9888):260-72. https://doi.org/10.1016/S0140-6736(13) 60687-X.

20. World Health Organization. Noncommunicable Diseases Progress Monitor, 2017 [Internet]. 2017 [cited 2019 Jan 26]. Available from: https://apps.who.int/iris/bitstream/handle/10665/258940/9789241513 029-eng.pdf;jsessionid=0CBCA236416C8A014F457F4F6CF998CF? sequence $=1$

21. Mayo Clinic. Chronic kidney disease - Diagnosis and treatment - Mayo Clinic [Internet]. 2019 [cited 2019 Mar 6]. Available from: https://www. mayoclinic.org/diseases-conditions/chronic-kidney-disease/diagnosistreatment/drc-20354527

22. NHS. Chronic kidney disease - Treatment - NHS [Internet]. 2019 [cited 2019 Mar 6]. Available from: https://www.nhs.uk/conditions/kidneydisease/treatment/

23. George C, Mogueo A, Okpechi I, Echouffo-Tcheugui JB, Kengne AP. Chronic kidney disease in low-income to middle-income countries: the case for increased screening. BMJ Glob Heal. 2017; 2(2). Available from: http://gh.bmj.com/content/2/2/e000256.abstract

24. Kirby T. Screening for chronic kidney disease shows promise. Lancet. 2010; 375(9722):1240-1. Available from: https://doi.org/10.1016/ S0140-6736(10)60527-2

25. G Couser W, Remuzzi G, Mendis S, Tonelli M. The contribution of chronic kidney disease to the global burden of major noncommunicable diseases. Kidney International. 2011. 80: 1258-1270.

26. Evans PD, Taal MW. Epidemiology and causes of chronic kidney disease Medicine. 2015;43(8):450-3. https://doi.org/10.1016/j.mpmed.2015.05. 005.

27. NHS. Chronic kidney disease - Diagnosis - NHS [Internet]. [cited 2019 Feb 28]. Available from: https://www.nhs.uk/conditions/kidney-disease/ diagnosis/

28. Sumaili EK, Cohen EP. Screening for chronic kidney disease in subSaharan Africa. Lancet [Internet]. 2010; 376(9739):418. 10.1016/ S0140-6736(10)61222-6

29. Stanifer JW, Muiru A, Jafar TH, Patel UD. Chronic kidney disease in low- and middle-income countries. Nephrol Dial Transplant. 2016; 31(6):868-74. Available from: https://www.ncbi.nlm.nih.gov/pubmed/ 27217391

30. Stanifer JW, Jing B, Tolan S, Helmke N, Mukerjee R, Naicker S, et al. The epidemiology of chronic kidney disease in sub-Saharan Africa: a systematic review and meta-analysis. Lancet Glob Heal. 2014;2(3):e174-81. https://doi.org/10.1016/S2214-109X(14)70002-6.

31. Abd ElHafeez S, Bolignano D, D'Arrigo G, Dounousi E, Tripepi G, Zoccali C. Prevalence and burden of chronic kidney disease among the general population and high-risk groups in Africa: a systematic review. BMJ Open. 2018; 8(1). Available from: http://bmjopen.bmj.com/content/8/ 1/e015069.abstract

32. Kaze AD, Ilori T, Jaar BG, Echouffo-Tcheugui JB. Burden of chronic kidney disease on the African continent: a systematic review and meta-analysis. BMC Nephrol. 2018;19(1):1-11. https://doi.org/10.1186/ s12882-018-0930-5.

33. Wyatt CM, Shi Q, Novak JE, Hoover DR, Szczech L, Mugabo JS, et al. Prevalence of kidney disease in HIV-infected and uninfected rwandan women. PLoS One. 2011;6(3):e18352. https://doi.org/10.1371/journal. pone.0018352.

34. Ministry of Health. Rwanda non-communicable diseases risk factors report [Internet]. 2015 [cited 2019 Jan 25]. Available from: http://www. who.int/chp/steps/Rwanda_2012_STEPS_Report.pdf?ua=1

35. Hill NR, Fatoba ST, Oke JL, Hirst JA, O'Callaghan CA, Lasserson DS, et al. Global prevalence of chronic kidney disease - a systematic review and meta-analysis. PLoS One. 2016; 11(7):e0158765e0158765. Available from: https://www.ncbi.nlm.nih.gov/pubmed/ 27383068

36. Gouda HN, Charlson F, Sorsdahl K, Ahmadzada S, Ferrari AJ, Erskine H, et al. Burden of non-communicable diseases in sub-Saharan Africa, 1990-2017: results from the Global Burden of Disease Study 2017. 
Lancet Glob Heal. 2019;7(10):e1375-87. https://doi.org/10.1016/S2214109X(19)30374-2.

37. Garcia-Garcia G, Jha V. Chronic kidney disease in disadvantaged populations. Indian J Nephrol. 2015; 25(2):65-9. Available from: https://www. ncbi.n/m.nih.gov/pubmed/25838641

38. GBD 2013 Mortality and Causes of Death Collaborators. Global, regional, and national age-sex specifi c all-cause and cause-specifi c mortality for 240 causes of death, 1990-2013: a systematic analysis for the Global Burden of Disease Study 2013. Lancet. 2015; 385(9963):117-71. 10.1016/S0140-6736(14)61682-2

39. Bikbov B, Perico N, Remuzzi G. Disparities in Chronic Kidney Disease Prevalence among males and females in 195 countries: analysis of the global burden of disease. Study Nephron. 2016;2018:313-8. https://doi. org/10.1159/000489897.

40. Jha V, Prasad N. CKD and infectious diseases in asia pacific: challenges and opportunities. Am J Kidney Dis. 2016;68(1):148-60. https://doi.org/ 10.1053/j.ajkd.2016.01.017

41. Luyckx VA, Tuttle KR, Garcia-Garcia G, Gharbi MB, Heerspink HJL, Johnson DW, et al. Reducing major risk factors for chronic kidney disease. Kidney Int Suppl. 2017;7(2):71-87 Available from: http://www.sciencedir ect.com/science/article/pii/S2157171617300291.

42. World Health Organization (WHO). A framework for surveillance- The WHO STEPwise approach to Surveillance of noncommunicable diseases ( STEPS ) [Internet]. 2003. Available from: http://www.who.int/ ncd_surveillance/en/steps_framework_dec03.pdf

43. World Health Organization (WHO). STEPwise approach to noncommunicable disease risk factor Surveillance (STEPS) [Internet]. 2019 [cited 2019 Jan 25]. Available from: https://www.who.int/ncds/surveillance/ steps/riskfactor/en/

44. World Health Organization. The STEPS Surveillance Manual [Internet]. 2017. 474 p. Available from: https://www.who.int/ncds/surveillance/ steps/STEPS_Manual.pdf

45. Sedgwick P. Multistage sampling. BMJ. 2015;351:h4155.

46. Ministry of Health (Rwanda). Rwanda non communicable diseases risk factors survey 2012-Survey Protocol. 2012.

47. Lavrakas P. Encyclopedia of survey research methods [Internet]. Thousand Oaks; 2008. Available from: http://methods.sagepub.com/refer ence/encyclopedia-of-survey-research-methods

48. World Health Organization (WHO). Module 8: blood collection - finger prick [Internet]. 2005. Available from: https://www.who.int/diagnostics_ laboratory/documents/guidance/module8_blood_collection_finge rprick.pdf?ua $=1$

49. PTS diagnostics. CardioChek PA analyzer [Internet]. 2018 [cited 2018 Dec 4]. Available from: https://ptsdiagnostics.com/cardiochek-pa-analy zer/

50. Uwera C. Re: NCDs Data. 2018.

51. COBAS [Internet]. 2019 [cited 2019 Jan 26]. Available from: https://diagn ostics.roche.com/

52. Casson RJ, Farmer LDM. Understanding and checking the assumptions of linear regression: a primer for medical researchers. Clin Experiment Ophthalmol. 2014;42(6):590-6. https://doi.org/10.1111/ceo.12358.

53. Statacorp. STATA software [Internet]. 2019 [cited 26 Jan 2019]. Available from: https://www.stata.com/

54. Unger T, Borghi C, Charchar F, Khan NA, Poulter NR, Prabhakaran D, et al. International society of hypertension global hypertension practice guidelines. Hypertension. 2020;75(6):1334-57. https://doi.org/10.1161/ HYPERTENSIONAHA.120.15026.

55. George JA, Brandenburg J-T, Fabian J, Crowther NJ, Agongo G, Alberts $M$, et al. Kidney damage and associated risk factors in rural and urban sub-Saharan Africa (AWI-Gen): a cross-sectional population study. Lancet Glob Heal. 2019;7(12):e1632-43. https://doi.org/10.1016/S2214109X(19)30443-7.

56. Mukakarangwa M, Chironda G, Bhengu B, G K. Adherence to hemodialysis and associated factors among end stage renal disease patients at selected nephrology units in Rwanda: a descriptive cross-sectional study. Nurs Res Pract. 2018; Available from: https://www.hindawi.com/ journals/nrp/2018/4372716/\#B14

57. Urbanisation, inequality, and non-communicable disease risk. Lancet Diabetes Endocrinol. 2017;5(5):313. Available from: https://www.thela ncet.com/pdfs/journals/landia/PIIS2213-8587(17)30116-X.pdf
58. Eckert S, Kohler S. Urbanization and health in developing countries: a systematic review. World Health Popul. 2014;15:7-20.

59. Cyril S, Oldroyd JC, Renzaho A. Urbanisation, urbanicity, and health: a systematic review of the reliability and validity of urbanicity scales. BMC Public Health. 2013;13(1):513. https://doi.org/10.1186/ 1471-2458-13-513.

60. Perkovic V, Cass A, Patel AA, Suriyawongpaisal P, Barzi F, Chadban S, et al. High prevalence of chronic kidney disease in Thailand. Kidney Int. 2008;73(4):473-9 Available from: http://www.sciencedirect.com/ science/article/pii/S0085253815530093.

61. Min R, Wang H, Zhang X, Li X, Fang P, Bai X. Facing the urban-rural gap in patients with chronic kidney disease: evidence from inpatients with urban or rural medical insurance in central China. PLoS One. 2018;13(12):e0209259 Available from: https://www.ncbi.nIm.nih. gov/pubmed/30596680.

62. Kaze FF, Meto DT, Halle M-P, Ngogang J, Kengne A-P. Prevalence and determinants of chronic kidney disease in rural and urban Cameroonians: a cross-sectional study. BMC Nephrol. 2015;16:117 Available from: https://www.ncbi.nlm.nih.gov/pubmed/26220538.

63. World Health Organization (WHO). Closing the gap in one generation: Health equity through action on the social determinants of health [Internet]. 2008 [cited 2019 Aug 3]. Available from: https:// apps.who.int/iris/bitstream/handle/10665/43943/9789241563703_ eng.pdf;jsessionid=08D0CEB8926F9F772B4F80894B68FADE?seque nce $=1$

64. Naicker S. End-stage renal disease in sub-Saharan Africa. Kidney Int Suppl. 2013;2013(3):161-3 Available from: https://www.kisuppleme nts.org/article/S2157-1716(15)31135-7/pdf.

65. World Health Organization (WHO). Health in all policies: framework for country action. 2013 [cited 3 Aug 2019]. p. 28. Available from: https://apps.who.int/iris/bitstream/handle/10665/112636/97892 41506908_eng.pdf;jsessionid=5A3099456028840A395EAFCC1049F7 Co? sequence $=1$

66. Huda MN, Alam KS, Harun-Ur-Rashid. Prevalence of chronic kidney disease and its association with risk factors in disadvantageous population. Int J Nephrol. 2012;2012:267329. https://doi.org/10.1155/ 2012/267329 Tesch G, editor.

67. Hilz R. Gender differences in the relationship between marital status and health-risk behaviour in Germany. Innov Aging. 2017;1 (suppl_1):193. https://doi.org/10.1093/geroni/igx004.736.

68. Eng PM, Kawachi I, Fitzmaurice G, Rimm EB. Effects of marital transitions on changes in dietary and other health behaviours in US male health professionals. J Epidemiol Community Health [Internet]. 2005;59(1):56 LP - 62. Available from: http://jech.bmj.com/content/ 59/1/56.abstract

69. Wekesah FM, Nyanjau L, Kibachio J, Mutua MK, Mohamed SF, Grobbee $D E$, et al. Individual and household level factors associated with presence of multiple non-communicable disease risk factors in Kenyan adults. BMC Public Health. 2018;18(3):1220. https://doi.org/10.1186/ s12889-018-6055-8

70. Hewitt B, Baxter J, Western M. Family, work and health: The impact of marriage, parenthood and employment on self-reported health of Australian men and women. J Sociol. 2006;42(1):61-78. https://doi.org/ 10.1177/1440783306061353.

71. Stimpson JP, Wilson FA, Peek MK. Marital status, the economic benefits of marriage, and days of inactivity due to poor health. Int J Popul Res. 2012;2012:568785. https://doi.org/10.1155/2012/568785 Schuler SR, editor.

72. Koball HL, Moiduddin E, Henderson J, Goesling B, Besculides M. What do we know about the link between marriage and health? J Fam Issues. 2010;31(8):1019-40. https://doi.org/10.1177/0192513X10365834.

73. Phaswana-Mafuya N, Peltzer K, Chirinda W, Musekiwa A, Kose Z. Sociodemographic predictors of multiple non-communicable disease risk factors among older adults in South Africa. Glob Health Action. 2013;6(1):20680. https://doi.org/10.3402/gha.v6i0.20680.

74. Yosef T. Prevalence and associated factors of chronic non-communicable diseases among cross-country truck drivers in Ethiopia. BMC Public Health. 2020;20(1):1564. https://doi.org/10.1186/ s12889-020-09646-w. 
75. Gojowy D, Więcek A. Chronic kidney disease and ageing. J Gerontol Geriatr. 2017 [cited 2019 Feb 20]; Available from: http://www.jgerontolo gy-geriatrics.com/article/chronic-kidney-disease-and-ageing/

76. Ferguson TW, Tangri N. Identifying potential biases in the nephrology literature. Adv Chronic Kidney Dis. 2016;23(6):373-6. https://doi.org/10. 1053/j.ackd.2016.11.013.

77. Zhang L, Zhang P, Wang F, Zuo L, Zhou Y, Shi Y, et al. Prevalence and factors associated with CKD: a population study from Beijing. Am J Kidney Dis. 2008;51(3):373-84. https://doi.org/10.1053/j.ajkd.2007.11.009.

78. Chang P-Y, Chien L-N, Lin Y-F, Wu M-S, Chiu W-T, Chiou H-Y. Risk factors of gender for renal progression in patients with early chronic kidney disease. Medicine. 2016;95(30):e4203 Available from: https://www.ncbi. nlm.nih.gov/pubmed/27472690.

79. United States Renal Data System. 2015 USRDS annual data report: epidemiology of kidney disease in the United States. [Internet]. 2015 [cited 2019 Aug 15]. Available from: https://www.usrds.org/2015/view/Defau It.aspx

80. Ploth DW, Mbwambo JK, Fonner VA, Horowitz B, Zager P, Schrader R, et al. Prevalence of CKD, diabetes, and hypertension in rural Tanzania. Kidney Int Reports. 2018;3(4):905-15 Available from: http://www.scien cedirect.com/science/article/pii/S2468024918300974.

81. Jungers P, Chauveau P, Descamps-Latscha B, Labrunie M, Giraud E, Man $\mathrm{N}$, et al. Age and gender-related incidence of chronic renal failure in a French urban area: a prospective epidemiologic study. Nephrol Dial Transplant. 1996;11(8):1542-6.

82. Inker LA, Shafi T, Okparavero A, Tighiouart H, Eckfeldt JH, Katz R, et al. Effects of race and sex on measured GFR: the multi-ethnic study of atherosclerosis. Am J Kidney Dis. 2016;68(5):743-51 Available from: http:// www.sciencedirect.com/science/article/pii/S0272638616303092.

83. Norris K, Nissenson AR. Race, gender, and socioeconomic disparities in CKD in the United States. J Am Soc Nephrol. 2008;19(7):1261-70 Available from: https://jasn.asnjournals.org/content/19/7/1261.short.

84. Orth SR, Hallan SI. Smoking: a risk factor for progression of chronic kidney disease and for cardiovascular morbidity and mortality in renal patients - absence of evidence or evidence of absence? Clin J Am Soc Nephrol. 2008;3(1):226 LP-236 Available from: http://cjasn.asnjournals. org/content/3/1/226.abstract.

85. Ishizaka N, Ishizaka Y, Toda E, Shimomura H, Koike K, Seki G, et al. Association between cigarette smoking and chronic kidney disease in Japanese men. Hypertens Res. 2008;31:485. https://doi.org/10.1291/ hypres.31.485.

86. Yacoub R, Habib H, Lahdo A, Al Ali R, Varjabedian L, Atalla G, et al. Association between smoking and chronic kidney disease: a case control study. BMC Public Health. 2010;10(1):731. https://doi.org/10.1186/ 1471-2458-10-731.

87. Bleyer AJ, Shemanski LR, Burke GL, Hansen KJ, Appel RG. Tobacco, hypertension, and vascular disease: risk factors for renal functional decline in an older population. Kidney Int. 2000;57(5):2072-9. https:// doi.org/10.1046/j.1523-1755.2000.00056.x.

88. Elihimas Júnior UF, Elihimas HC d S, Lemos VM, Leão M d A, Sá MPB d O, França EET d, et al. Smoking as risk factor for chronic kidney disease: systematic review. Brazilian Journal of Nephrology Scielo. 2014;36:519-28.

89. Lindbohm JV, Kaprio J, Korja M. Survival bias explains improved survival in smokers and hypertensive individuals after aSAH. Neurology. 2019;93(23):e2105.LP-e2109 Available from: http://n.neurology.org/ content/93/23/e2105.abstract.

90. Chang C-CH, Zhao Y, Lee C-W, Ganguli M. Smoking, death, and Alzheimer disease: a case of competing risks. Alzheimer Dis Assoc Disord. 2012;26(4):300-6 Available from: https://pubmed.ncbi.nlm.nih.gov/ 22185783.

91. Wang X, Ouyang Y, Liu J, Zhu M, Zhao G, Bao W, et al. Fruit and vegetable consumption and mortality from all causes, cardiovascular disease, and cancer: systematic review and dose-response meta-analysis of prospective cohort studies. BMJ. 2014;349:g4490 Available from: http:// www.bmj.com/content/349/bmj.g4490.abstract.

92. Hung H-C, Joshipura KJ, Jiang R, Hu FB, Hunter D, Smith-Warner SA, et al. Fruit and vegetable intake and risk of major chronic disease. J Natl Cancer Inst. 2004;96(21):1577-84. https://doi.org/10.1093/jnci/djh296.

93. Nguyen B, Bauman A, Gale J, Banks E, Kritharides L, Ding D. Fruit and vegetable consumption and all-cause mortality: evidence from a large
Australian cohort study. Int J Behav Nutr Phys Act. 2016;13(1):9. https:// doi.org/10.1186/s12966-016-0334-5.

94. La Vecchia C, Decarli A, Pagano R. Vegetable consumption and risk of chronic disease. Epidemiology. 1998;9(2):208-10 Available from: http:// www.jstor.org/stable/3702963.

95. Jhee JH, Kee YK, Park JT, Chang T-I, Kang EW, Yoo T-H, et al. A diet rich in vegetables and fruit and incident CKD: a community-based prospective cohort study. Am J Kidney Dis. 2019. https://doi.org/10.1053/j.ajkd.2019. 02.023 .

96. Naicker S, Rahmanian S, Kopp JB. HIV and chronic kidney disease. Clin Nephrol. 2015;83(7 Suppl 1):32-8 Available from: https://www.ncbi.nlm. nih.gov/pubmed/25725239.

97. Ekrikpo UE, Kengne AP, Bello AK, Effa EE, Noubiap JJ, Salako BL, et al. Chronic kidney disease in the global adult HIV-infected population: a systematic review and meta-analysis. PLoS One. 2018;13(4):e0195443. https://doi.org/10.1371/journal.pone.0195443.

98. Ibrahim F, Hamzah L, Jones R, Nitsch D, Sabin C, Post FA, et al. Comparison of CKD-EPI and MDRD to estimate baseline renal function in HIVpositive patients. Nephrol Dial Transplant. 2011;27(6):2291-7. https:// doi.org/10.1093/ndt/gfr657.

99. Wyatt CM. Kidney disease and HIV infection. Top Antivir Med. 2017;25(1):13-6 Available from: https://pubmed.ncbi.nlm.nih.gov/ 28402929.

100. Phair J, Palella F. Renal disease in HIV-infected individuals. Curr Opin HIV AIDS. 2011;6(4):285-9 Available from: https://pubmed.ncbi.nlm.nih. gov/21519246.

101. Achhra AC, Nugent M, Mocroft A, Ryom L, Wyatt CM. Chronic kidney disease and antiretroviral therapy in HIV-positive individuals: recent developments. Curr HIV/AIDS Rep. 2016;13(3):149-57.

102. Mocroft A, Lundgren JD, Ross M, Fux CA, Reiss P, Moranne O, et al. Cumulative and current exposure to potentially nephrotoxic antiretrovirals and development of chronic kidney disease in HIV-positive individuals with a normal baseline estimated glomerular filtration rate: a prospective international cohort study. Lancet HIV. 2016;3(1):e23-32 Available from: http://www.sciencedirect.com/science/article/pii/\$2352 301815002118.

103. Panel of experts from GESIDA of SEIMC the S.E.N. and the SEQCa, Górriz $J \mathrm{~L}$, Gutiérrez F, Trullas JC, Arazo P, Arribas JR, et al. Consensus document on the management of renal disease in HIV-infected patients. Nefrol. 2014;34:1-81 Available from: https://www.revistanefrologia.com/enconsensus-document-on-management-renal-disease-in-hiv-infectedpatients-articulo-X2013251414054695.

104. McMahon GM, Preis SR, Hwang S-J, Fox CS. Mid-adulthood risk factor profiles for CKD. J Am Soc Nephrol. 2014;25(11):2633.LP-2641 Available from: http://jasn.asnjournals.org/content/25/11/2633.abstract.

105. Foster MC, Hwang S-J, Larson MG, Lichtman JH, Parikh NI, Vasan RS, et al. Overweight, obesity, and the development of stage 3 CKD: The Framingham Heart Study. Am J Kidney Dis [Internet]. 2008;52(1):39-48 Available from: http://www.sciencedirect.com/science/article/pii/S0272 638608005751.

106. Setia MS. Methodology series module 3: cross-sectional studies. Indian J Dermatol. 2016;61(3):261-4 Available from: https://www.ncbi.nlm.nih. gov/pubmed/27293245.

107. Pavkov ME, Knowler WC, Hanson RL, Bennett PH, Nelson RG. Predictive power of sequential measures of albuminuria for progression to ESRD or death in Pima Indians with type 2 diabetes. Am J Kidney Dis. 2008. 2008; 51(5):759-66. Available from: https://pubmed.ncbi.nlm.nih.gov/ 18436086

108. Kröpelin TF, de Zeeuw D, Andress DL, Bijlsma MJ, Persson F, Parving $\mathrm{H}-\mathrm{H}$, et al. Number and frequency of albuminuria measurements in clinical trials in diabetic nephropathy. Clin J Am Soc Nephrol. 2015; 10(3):410 LP - 416. Available from: http://cjasn.asnjournals.org/content/10/3/410. abstract

109. Bottomley MJ, Kalachik A, Mevada C, Brook MO, James T, Harden PN. Single estimated glomerular filtration rate and albuminuria measurement substantially overestimates prevalence of chronic kidney disease. Nephron Clin Pract. 2011;117(4):348-52. https://doi.org/10.1159/000321515.

110. Stevens LA, Schmid CH, Greene T, Zhang YL, Beck GJ, Froissart M, et al. Comparative performance of the CKD Epidemiology Collaboration (CKD-EPI) and the Modification of Diet in Renal Disease (MDRD) Study equations for estimating GFR levels above $60 \mathrm{~mL} / \mathrm{min} / 1.73 \mathrm{~m} 2$. Am J 
Kidney Dis. 2010. 56(3):486-95. Available from: https://pubmed.ncbi. nlm.nih.gov/20557989

111. Lamb E. Assessment of kidney function in adults. Medicine. 2015;43(7):368-73. https://doi.org/10.1016/j.mpmed.2015.04.005.

112. Association of estimated glomerular filtration rate and albuminuria with all-cause and cardiovascular mortality in general population cohorts: a collaborative meta-analysis. Lancet. 2010; 375(9731):2073-81. 10.1016/ S0140-6736(10)60674-5

113. Matsha TE, Erasmus RT. Chronic kidney disease in sub-Saharan Africa. Lancet Glob Heal. 2019;7(12):e1587-8. https://doi.org/10.1016/S2214109X(19)30467-X

114. Hemmati R, Gharipour M, Khosravi A, Jozan M. A cost-benefit and accurate method for assessing microalbuminuria: single versus frequent urine analysis. Int J Hypertens. 2013;2013:752903 Available from: https://pubmed.ncbi.nlm.nih.gov/24455207.

115. Zamanzad B. Accuracy of dipstick urinalysis as a screening method for detection of glucose, protein, nitrites and blood. East Mediterr Heal J. 2009;15(5):1313-22 Available from: http://www.emro.who.int/ emhj-volume-15-2009/volume-15-issue-5/accuracy-of-dipstick-urina lysis-as-a-screening-method-for-detection-of-glucose-protein-nitritesand-blood.html.

116. White SL, Yu R, Craig JC, Polkinghorne KR, Atkins RC, Chadban SJ. Diagnostic accuracy of urine dipsticks for detection of albuminuria in the general community. Am J Kidney Dis. 2011;58(1):19-28. https://doi.org/ 10.1053/j.ajkd.2010.12.026.

117. Kazancioğlu R. Risk factors for chronic kidney disease: an update. Kidney Int Suppl. 2013;3(4):368-71 Available from: https://www.ncbi.nlm. nih.gov/pubmed/25019021

118. Grimes DA, Schulz KF. Bias and causal associations in observational research. Lancet. 2002;359(9302):248-52 Available from: http://www. sciencedirect.com/science/article/pii/S0140673602074512.

119. (NISR) NI of S of R. Fourth population and housing census, Rwanda, 2012, Population size, structure and. 2012

\section{Publisher's Note}

Springer Nature remains neutral with regard to jurisdictional claims in published maps and institutional affiliations.
Ready to submit your research? Choose BMC and benefit from:

- fast, convenient online submission

- thorough peer review by experienced researchers in your field

- rapid publication on acceptance

- support for research data, including large and complex data types

- gold Open Access which fosters wider collaboration and increased citations

- maximum visibility for your research: over $100 \mathrm{M}$ website views per year

At BMC, research is always in progress.

Learn more biomedcentral.com/submissions 